\title{
BEBERAPA FAKTOR SOSIO-ANTROPOLOGIS YANG MENDORONG PERLUNYA REFORMULASI PEMIKIRAN HUKUM DALAM ISLAM
}

\author{
Roibin*
}

\begin{abstract}
A bstract: We have moved away from the era of the prophet, the exemplary disciples of the prophet, the founders of the madhhab, and the era of the classical 'ulama. This periodical "moving away" has a tremendous impact on the way we understand Islam. While the revelation has long been ceased since the passing away of the prophet, our social and cultural problems have at the same time increased and intensified. This requires a serious ijtihad to solve some serious problems facing our society. We are obliged to exercise our utmost intellectual ability to extrapolate what Islam has to say concerning these problems. During the lifetime of the prophet, Muslims could consult him on all issues facing them. Vis-à-vis this, the prophet could always offer a satisfactory answer due to his prudence, intellectual acumen, and indeed divine guidance. Muslims living in the post-prophetic eras have to accept that the prophet is no longer with them. They have to rely on their ability to do the ijtihad by interpreting and reinterpreting the divine texts, articulating the views of the previous 'ulama, and proposing new ideas in line with the spirit of the Q ur'an and the prophetic tradition. This paper deals with the complexity of ijtihad in modern time by highlighting the necessity of reformulating the Islamic thought on Divine Law so that the teachings of Islam may stay relevant to the demand of modern man.
\end{abstract}

Keywords: reformulation, Islamic law, social and anthropological factors

\section{Pendahuluan}

Gagasan kritis analitis seputar hak-hak asasi, antara lain hak untuk mengutarakan pendapat dan gagasan, secara kebetulan telah mempertanyakan untuk apa hukum itu dibuat. Karena hukum bagi perspektif kritis hak-hak asasi, pada satu sisi merupakan bentuk kekangan terhadap kebebasan manusia. Sementara kekangan tersebut meskipun sedikit menuntut adanya alasan/ pembenaran yang kuat. Alasan pembenaran yang kuat inilah yang dalam bahasa agama disebut sebagai maksud shara' atau hikmah di balik aturan atau ikatan diperlukannya hukum tersebut bagi manusia.

Bermula dari sinilah muncul berbagai kubu penyikapan terhadap eksistensi diterbitkannya hukum secara eksplisit bagi manusia. Sebagian kubu mengatakan bahwa kesadaran manusia akan terpola dengan baik oleh karena keberadaan nurani manusia yang telah mewakili secara implisit terhadap eksistensi hukum tersebut. Pada sisi lain mengatakan bahwa kesadaran manusia tidak akan pernah terbentuk tanpa adanya ikatan-ikatan secara eksplisit dari aturan-aturan hukum secara formal. Tarik menarik dua kubu di atas pada gilirannya melahirkan aliran esensialis pada satu sisi dan aliran formalis pada sisi lain. Model pertama: cenderung menolak adanya teks-teks

\footnotetext{
* Dosen Antropologi Hukum Islam, Sosiologi Hukum Islam (Tarikh Tasyri'), dan Pendekatan Studi Islam pada Fakultas Syari'ah dan Program Pascasarjana UIN Malang.
} 
hukum yang diformalkan sebagai hukum positif. Sementara yang kedua: mengapresiasi munculnya formalisasi teks-teks hukum dalam kehidupan. Perbedaan cara pandang ini tentu saja dilatarbelakangi oleh cara pandang pemahaman konsepsi hukum yang berbeda pula.

Roscoe Pound ${ }^{1}$ misalnya, mengatakan sedikitnya ada 12 konsepsi hukum dan masingmasing punya arti yang berbeda-beda. Di antara ke-12 (duabelas) konsepsi hukum tersebut antara lain ada yang difahami dan ditafsirkan bahwa hukum adalah tradisi dari kebiasaan lama yang telah disepakati oleh para dewa, karena ia dianggap sebagai penunjuk jalan manusia. Sementara itu, hukum juga diartikan sebagai refleksi kebijakan/kepentingan dari penguasa. Di pihak lain hukum dipahami sebagai kaidah-kaidah yang diturunkan oleh Tuhan untuk mengatur kehidupan manusia.

Konsepsi hukum di atas, masing-masing pesannya mempunyai penekanan sendiri-sendiri. Contoh konsep hukum pertama penekanannya didasarkan pada tradisi dari kebiasaan lama. Sementara model kedua tekanan hukumnya tergantung kepada upaya-upaya kepentingan/ kebijakan dari penguasa. Sedangkan model yang terakhir semangat hukumnya bersinergi dengan situasi dan kondisi perkembangan masyarakatnya. Tiga contoh pemahaman tentang konsep hukum di atas masing-masing memiliki dampak implikasi sosial dan moral yang sangat berbeda. Maka wajarlah jika sebagian menyikapi negatif, jika yang dimaksud hukum tersebut justru akan menghegemoninya.

\section{Karakteristik Hukum Islam}

Keragaman cara pandang pemahaman hukum di atas, hukum Islamlah yang secara substansial memiliki kedekatan karakteristik dengan pemahaman hukum yang terakhir, yaitu semangat hukumnya bersinergi dengan konteks sosio-kulturalnya. Dalam aplikasinya, ia memiliki fungsi ganda. Pertama: fungsi bashipa>yaitu fungsi penggembira, pemotivasi dan pendorong. Kedua: fungsi nadhira,yaitu fungsi peringatan dan ancaman. Pertama, bisa jadi sikap manusia terhadap hukum tersebut merasakan adanya kekangan-kekangan atas peringatan dan ikatan yang terdapat dalam wahyu-Nya. Namun karena fungsi bashipa,ppada langkah berikutnya manusia akan menyadari akan pentingnya peringatan-peringatan, ikatan-ikatan yang disertai dengan berbagai ancaman Tuhan. Kesadaran ini muncul karena atas fungsi bashipa, sebagai fungsi penggembira, pemotivasi yang diiringi dengan janji-janji Tuhan.

Di sanalah akan terjadi proses dialektik dan tawar menawar suatu hukum, yaitu antara hukum Tuhan yang bercorak ancaman dan peringatan dengan hukum Tuhan yang bercorak balasan dan pahala. Tawar menawar itu pada gilirannya akan melahirkan kesadaran manusia untuk menggabungkan dua corak pesan ayat Tuhan tersebut. Tawar menawar tersebut bukan berarti membuka kemungkinan untuk melakukan perubahan-perubahan teks yang telah tersusun secara sistematis. Tetapi tawar menawar itu lebih menyentuh pada muatan atau ruh dari teks wahyu yang sangat adaptif, komunikatif, dialogis dan kompromistik terhadap tuntutan perkembangan sosial budayanya. Fenomena dialogis itu bisa kita amati lebih dalam pada

\footnotetext{
${ }^{1}$ Roscoe Pound, An Introduction to the Philosopy of Law ; Pengantar Filsafat Hukum, diterjemah oleh Drs. M. Radjab ( J akarta: B hratara, 1989), 28-30.
} 
peristiwa asbab al-nuzul»teks tersebut, yang selalu terkait dengan fenomena pra kehidupan masyarakat Arab dan Arab ketika itu.

Inilah sebabnya, hukum Islam dalam konteks kesejarahan tidak pernah menampakkan sifatnya yang kaku. Fungsi pertama selalu berinteraksi dengan fungsi kedua. Dengan kata lain ketika manusia mengalami tekanan-tekanan, ikatan-ikatan akan suatu hukum, pada saat yang sama mereka menyadari bahwa di balik itu semua terdapat kemudahan-kemudahan, kemenangan-kemenangan dari sejumlah janji-janji Tuhan yang lain.

Sama saja artinya manusia dihadapkan pada dua pilihannya, tanpa harus memaksakan kehendaknya. Di satu pihak hukum Islam memiliki sifatnya yang doktriner dan normatif, namun di pihak lain ia menerima perubahan-perubahan, dan dalam aplikasinya selalu ada pintu ijtihad yang memberi ruang untuk menyesuaikan dengan realitas empiriknya. Oleh karenanya tidak heran jika dalam kaidah-kaidah fiqhiłah banyak yang bersinggungan dengan argumentasi di atas.

Sebut saja misalnya, al-hykm yadurma'a 'illatih wujuda wa 'adama łhukum itu mengikuti ada atau tidak adanya illat). Al-dørurah tubih al-makhdy rat(darurat itu membolehkan sesuatu yang dilarang). Demikian juga dalam dunia politik dikenal juga kaidah ma ła yudrak kulluh la> yutrak kulluh (apa yang tidak bisa diperoleh semuanya, jangan ditinggalkan semuanya).

Sementara dalam hal budaya dan peradaban berpegang pada kaidah al-muhafad ah 'ala> al-qadimi al-salinhwa al-akhd bi al-jadid al-aslah (memelihara produk budaya lama yang baik dan mengambil produk budaya baru yang lebih baik). ${ }^{2}$

Dari berbagai pendekatan kaidah-kaidah di atas, ada kesan bahwa ajaran Islam selalu sesuai dengan prinsip-prinsip perkembangan dan dinamika masyarakat. Pandangan di atas senada dengan tiga asas penerapan hukum dalam pemikiran H udlari. ${ }^{3}$ Pertama; 'adam al-haraj (tidak mempersulit), kedua; takhfißal-taklif(memperingan beban), ketiga; al-tadrij(berangsurangsur, tahap demi tahap). Pandangan serupa sebagaimana telah disabdakan oleh Nabi beberapa abad sebelumnya, yang bersisi : tidaklah dipilih dua hal, melainkan saya memilih yang paling mudah, sepanjang pilihan tersebut tidak termasuk perbuatan dosa. ${ }^{4}$

Tiga asas penerapan hukum menurut pandangan Hudlari dalam praktiknya masih terus mengalami perkembangannya. Antara lain hukum bisa berarti sebagai al-tashi's(motivasi). Fungsi ini bisa kita amati dalam ayat-ayat al-Q ur'an yang muatannya terkesan hanya berlaku untuk budaya lokal masyarakat pra Arab dan Arab ketika itu. Kalimat al-jannah tajri min tahtiha alanhar misalnya, adalah salah satu contoh ilustrasi kehidupan akhirat. Dengan ilustrasi ini Tuhan bermaksud memberikan al-tashji's(motivasi) kepada komunitas tertentu.

Ilustrasi ini akan terasa sangat indah jika berlaku untuk masyarakat yang secara geografis memiliki iklim yang panas dan jauh dari air, lebih-lebih di gurun pasir. Oleh karena itu teks di atas akan berfungsi lebih tepat dan benar-benar akan menjadi al-tashii's jika diturunkan untuk masyarakat Arab setempat. Sebaliknya akan berbeda maksud dan pesannya jika pesan hukum

\footnotetext{
${ }^{2}$ Syafi'i Ma'arif, Islam dan Masalah-masalah Kenegaraan (J akarta: LP3S,1985), h.

${ }^{3}$ M. Hudlari Bek, Tarikh Tashri’>al-Islami łMesir: al-Maktabah al-Tashriłłah al-Kubrał, h.

${ }^{4}$ Manshur Amin, Ismail S. A hmad (ed), Dialog Pemikiran Islam dan Realitas Empirik (Yogyakarta: LKPSM NU, 1993), vii.
} 
tersebut diberlakukan pada masyarakat pegunungan misalnya, yang kesehariannya sudah menyatu dan banyak bersentuhan dengan air yang melimpah.

Pemahaman kontekstual seperti ini akan memiliki konsekuensi-konsekuensi, antara lain, jika ayat tersebut diturunkan di Indonesia, maka yang disebut al-jannah adalah sesuatu yang paling menarik dan memberi motivasi bagi mayoritas bangsa Indonesia. Bisa jadi berupa kekayaan, karena mayoritas bangsa Indonesia adalah miskin. Ilustrasi al-jannah tersebut akan berbeda juga jika diturunkan di tempat lain. Ini artinya tergantung kepada motivasi dari masingmasing situasi dan kondisi budaya bangsa. Dari sini bisa diamati bahwa betapa hukum Tuhan yang diperuntukkan manusia selalu sinergi dengan perkembangan dan budaya manusia yang ada.

Al-Qur'an-sebagai sumber utama hukum Islam-turun di hadapan umat Muhammad Saw., tidak lain adalah sebagai jawaban atas berbagai fenomena sosial pada kurun masyarakat tertentu. Ada kalanya turun dalam wujudnya sebagai nadhira $>$ dan terkadang sebagai bashira $>$ Wujud pertama lebih dominan sebagai peringatan-peringatan, yang acap kali diturunkan di tengah masyarakat yang belum menyadari akan makna kebenaran hukum secara universal. Sehingga perilaku kesehariannya banyak dijumpai beberapa penyimpangan moral. Sebaliknya model kedua banyak diturunkan pada suatu masyarakat yang telah menyadari akan makna Tuhan tersebut, baik dalam wujudnya sebagai nadhira atau bashira.Keduanya selalu menggunakan format hukum yang selalu disesuaikan dengan bahasa mereka, baik bahasa sosial budayanya maupun kemampuannya. Oleh karena itu tidak terlalu heran jika dalam kenyataannya, beberapa teks al-Q ur'an yang ada, banyak yang menunjukkan karakteristik masyarakat pra Arab dan Arab ketika itu. Demikianlah bahasa al-Qur'an yang sangat respon pada bahasa kaumnya.

Benarkah para ahli hukum klasik, pertengahan dan kontemporer dalam menggali sumber hukum selalu mengkaitkan dengan kondisi sosio-kulturalnya? Sebagaimana layaknya al-Q ur'an diturunkan di hadapan umat Muhammad Saw. Untuk melihat bagaimana respon para ahli hukum terhadap perkembangan budayanya, kaitannya dengan upaya reformulasi pemikiran hukum Islam, bisa kita amati perkembangan sejarah hukum sebagaimana berikut.

Sedemikian besarnya pengaruh situasi dan kondisi kota Kufah dan Bagdad yang metropolitan itu, hingga bisa melahirkan sosok ulama ahl al-ra'y dengan pelopornya Imam Abu $\mathrm{H}$ anifah. A kibat dari pengaruh tersebut mengharuskan Imam Abu Hanifah mampu menghadapi sejumlah persoalan baru yang muncul akibat kompleksitas kehidupan kota yang sangat rasional. Belum lagi ditambah dengan kenyataan bahwa Bagdad terletak jauh dari kota hadith, yaitu Madinah. Dengan begitu sangat masuk akal-sebab pengaruh situasi dan kondisi-jika pada akhir perjalanan Imam Abu Hanifah dan murid-muridnya banyak yang menulis kitab-kitab figh yang lebih mendasarkan kepada ra'y (akal) dari pada hadith yang tidak masyhur.

Berbeda dengan Imam Malik bin Anas yang hidup di kota Madinah. Dimana tingkat kompleksitas kotanya relatif lebih sederhana, apalagi ditandai dengan banyaknya hadith yang beredar di kota tersebut. Tentu kondisi ini akan berpengaruh pada intensitas penggunaan hædith yang lebih tinggi dibanding dengan rasio. $\mathrm{Hal}$ ini bisa dibenarkan lewat karyanya, yaitu alMuwat娥, di mana kitab ini merupakan kumpulan hædith pertama, yang sekaligus sebagai kitabkitab fiqh yang mendasarkan pada hædith atau riwayat. 
Contoh serupa bisa kita baca dalam kitab al-Mahalla>Dari kitab ini kita akan menemui pernyataan tentang qawl qadim dan jadid Imam Shafi'i>Dari sini pula akan muncul pertanyaan, yang terkait dengan persoalan yang melatarbelakangi munculnya qawl qadim dan jadid Imam Shafi'i iŁersebut. J awaban sementara mengatakan, bahwa faktor situasi dan kondisi masyarakat telah diduga banyak mempengaruhi lahirnya berbagai mazhab fiqh dalam Islam.

Pada perkembangan berikutnya, yaitu bergeser ke abad 12, di sana dijumpai kitab Bidayat al-M ujtahid, karangan Ibn Rushd. Di mana dalam berbagai hal, kitab tersebut tidak condong ke salah satu mazhab tertentu, melainkan kitab tersebut menyajikan aneka ragam pendapat, sekaligus dengan alasan-alasannya. Atas dasar itu, bisa disimpulkan bahwa kecenderungan figh muqaranah baru berkembang lebih pesat pada zaman modern ini, di mana ketika tingkat urbanisme masyarakat muslim di dunia telah semakin meningkat.

Tentu karakteristik kitab ini tidak akan pernah lepas dari kondisi budaya di mana Ibn Rushd hidup. Beliau ketika tinggal di Cordova, Spanyol, pada saatnya tempat tersebut telah menjadi kota metropolitan. Sejarahwan telah mencatat bahwa Cordova ketika itu terdiri dari 21 perkampungan dengan 13.000 buah rumah, memiliki 70 perpustakaan, sejumlah toko-toko buku, masjid dan bangunan istana. Di samping pada saat itu Cordova juga memiliki jaringan jalan umum dengan menggunakan batu-batu di sepanjang jalan yang dilengkapi dengan lampulampu lentera. Sementara di London beberapa abad kemudian masih gelap gulita. Bahkan di Paris beberapa saat setelah itu orang masih berjalan di atas lumpur setinggi lutut. Demikianlah jauhnya perbedaan kota Islam Cordova dengan kota-kota di Eropa waktu itu. Kompleksitas kehidupan Ibn Rushd di kota inilah, ditambah dengan fakta bahwa Ibn Rushd sendiri adalah seorang filosof yang berpandangan luas, yang pada akhirnya berhasil mewarnai kitabnya yang sangat netral itu.

Tradisi dinamika Bagdad dan Cordova dalam melahirkan kitab-kitab fiqh ternyata tidak bisa dikembangkan di sebagian besar negeri lainnya. Hal demikian bisa kita amati jika kita bergeser ke abad 19-20. Kita akan menemukan bahwa berbagai negeri Muslim seperti di Asia Tenggara, akan lebih tertarik mempelajari kitab fiqh yang matang, tanpa harus mengetahui bagaimana proses perkembangan dari kitab tersebut. Meskipun kitab yang hendak dikaji adalah kitab yang lama yang jauh dan ditulis pada tempat yang berbeda iklim sosio-kulturalnya. Mengapa pada abad-abad ini orang-orang Islam menjadi pengagum karya orang lain yang muncul beberapa abad yang lalu tanpa memandang tingkat relevansinya? ${ }^{5}$ Tanpa disadari, berarti kita menjadi penganut agama yang berpikir dalam kerangka romantisisme-historis, dengan mencoba bernostalgia, memuja-muja, hingga berakhir pada tahap pengkultusan sejarah. Akan lebih memprihatinkan lagi jika mereka telah berupaya untuk mempertahankan, memapankan hasil interpretasi ajaran keagamaan yang telah dilakukan oleh para pelaku sejak awal, tanpa berminat sedikitpun untuk mengkompromikan dengan corak pemahaman keagamaan yang datang kemudian. ${ }^{6}$

\footnotetext{
${ }^{5}$ Cik Hasan Bisri, (ed),H ukum Islam dalam Tatanan Masyarakat Indonesia (J akarta: Logos, 1998), 4-6.

${ }^{6}$ Roibin, Respon Agama di Tengah Perubahan Sosial, makalah diseminarkan pada mahasiswa angkatan 2001/2002 STAIN Malang, 12/8/2001.
} 
B eberapa contoh di atas cukup menjadi bukti sejarah, bahwa bergantinya waktu dan tempat menyebabkan munculnya pandangan yang beragam di kalangan ulama mengenai tanggapannya terhadap kehendak Tuhan. Dalam kaitannya untuk menilai posisi wanita misalnya, Iraq nampaknya lebih baik dari pada Hijaz. Perbedaan ini tentu sangat dipengaruhi oleh perbedaan geografis. Secara geografis Iraq adalah daerah yang hidup bertetangga dengan Persia, yaitu daerah yang memiliki latar budaya lama dan lebih maju.

Dengan demikian dalam kehidupan sosialnya, Iraq banyak dipengaruhi oleh Persia, sementara Arab (utamanya $\mathrm{Hijaz}$ ), adalah negeri yang cukup murni dari pengaruh kebudayaan yang sudah maju. Faktor inilah yang membuat pandangan Iraq semakin baik terhadap wanita. ${ }^{7}$

\section{Reformulasi Pemikiran Hukum Islam: Sebuah Keniscayaan}

Kini kita berada pada suatu generasi yang hidup jauh dari kehidupan Rasul, al-KhulafasalRashidun, para imam mazhab, Atba' al-Tabi'in dan fuqaha'> klasik. Tidak saja jauh dalam pengertian rentang waktu, melainkan jauh dalam arti corak berikut karakteristik budaya dan peradabannya. Setiap fenomena sosial budaya yang berkembang dengan aneka ragamnya, tidak lagi memperoleh petunjuk/jawaban secara langsung yang turun dari Allah (wahyu), sebagaimana ketika Rasul menghadapi fenomena serupa pada masanya. Setiap kali beliau menghadapi problem krusial, ketika itu pula tiba-tiba al-Qur'an turun sebagai jawabannya. Demikian juga setiap fenomena yang dijumpai masyarakat Muslim pada era awal selalu saja Rasul dijadikan sebagai figur oto ritatif untuk memberikan jawaban-jawabannya. Dengan demikian ketergantungan tafsir dan solusi terhadap berbagai permasalahan hukum dan kehidupan pada era awal selalu berkiblat kepada Rasul. Namun demikian, sejak beliau berpulang ke rahmatullah, marja' hukum tidak lagi berkiblat kepada satu figur tertentu. Sejak itulah para fuqahas mulai membangun otoritas kemandirian keilmuannya. Secara perlahan mereka dihadapkan pada permasalahan-permasalahan hukum yang sangat bervariatif. Sementara itu budaya yang berkembang di eranya memiliki motif yang jauh berbeda, yang tidak dijumpai pada era-era sebelumnya.

Inilah suatu masa, di mana generasinya telah dihadapkan pada beban-beban barunya. Belum lagi ditambah dengan hilangnya beberapa figur agama di atas, yang memiliki otoritas penuh di bidang keagamaan.

Fenomena di atas merupakan bukti riil dari beberapa agenda permasalahan yang dianggap cukup berat bagi agamawan-agamawan belakangan. Mereka dituntut untuk melakukan upayaupaya interpretasi terhadap teks, memilahnya secara rinci, berikut mengartikulasikannya, agar bisanya pesan al-Qur'an selalu berinteraksi, beradaptasi dan bersosialisasi senada dengan perkembangan budayanya. Itulah sebabnya desakan akan perlunya upaya formulasi pemikiran hukum Islam menjadi suatu keniscayaan.

Sementara permasalahan lain, dalam rentang waktu yang relatif lama ini, belum tampil metodologi (usjulfiqh) produk ulama modern, yang relevan dengan kontek budayanya. Sehingga keinginan upaya reformulasi pemikiran hukum Islam yang amat mendesak, belum diimbangi

${ }_{7}^{7}$ A mir Syarifuddin, Pembaharuan Pemikiran dalam Hukum Islam. (Padang: Angkasa Raya. 1993), 102. 
dengan langkah metodologi barunya. U paya reformulasi pemikiran hukum Islam, kini tampak berserakan (kalau tidak disebut sebagai pengulangan ide lama). Sebagian masih menggunakan metodologi yang diterbitkan oleh ulama beberapa abad yang lalu, tanpa melihat relevansi perkembangan budayanya. Di satu pihak hanya berbekal dengan keyakinan daya nalarnya, yang secara kualitatif belum banyak diakui. Fakta ini pada akhirnya hanya akan mempertajam perbedaan-perbedaan hasil penggalian suatu hukum yang tanpa dasar.

Perbedaan pandangan dalam penafsiran hukum, memang kita akui muncul sejak sepeninggal Rasul. Perbedaan tersebut adakalanya disebabkan oleh perbedaan metodologi, terdapatnya lafazflafazhomonim dalam teks al-Q ur'an, dan yang terakhir-sebagai sumber pemicu utama-karena belum diterbitkannya metodologi sistematis untuk menggali suatu hukum.

Berbagai perbedaan yang sangat tajam di atas sedikit agak terkurangi, ketika Imam Shafi' i> berhasil merumuskan suatu metodologi (uskllfiqh) secara sistematis dalam kitabnya yang berjudul al-Risalah. Melalui karyanya itu ia telah diakui dengan penuh penghargaan sebagai peletak utama dasar metodologi pemahaman hukum dalam Islam. Melalui karyanya pula tidak saja ia diakui dan diikuti oleh mazhabnya sendiri, melainkan diakui pula oleh seluruh mazhab di luar Imam Shafi'i>Sejak itulah ia dihargai dengan penuh oleh dunia kesarjanaan Islam, di samping beberapa apresiasi kekaguman yang terus bermunculan dari kalangan dunia kesarjanaan modern pada umumnya. ${ }^{8}$

Karya monumental Imam Shafi'iłersebut pada masanya telah mengangkat nama baik bagi peradaban Islam, namun pada perkembangan berikutnya secara tidak langsung telah menjadi penyebab pasifnya daya kreatifitas generasi yang datang kemudian. Hal ini terbukti sejak munculnya karya tersebut di dunia Islam, hingga kini belum ditemui metodologi (usklbfiqh) jenis lain yang kapasitasnya sebanding dengan metodologi Imam Shafi'i itersebut.

Beberapa forum kajian Islam misalnya, yang mengatasnamakan kelompoknya sebagai pembaru dalam pemikiran Islam, ternyata pemikiran yang muncul masih sebatas semangat pembaharuannya, dan belum menyentuh pada bekal pisau analisis (usjlbfiqh) yang baku. Lebihlebih kajian hukum yang sering terjadi di dua organisasi besar, yaitu Bahtsul Masail (sebagai nama kajian di organisasi NU) dan Tarjih (sebagai nama kajian di organisasi Muhammadiyah). Keduanya masih berkutat dalam mempertahankan mazhabnya masing-masing, yang tidak jarang dalam kajiannya masih selalu merujuk kaidah-kaidah metodologi Imam Shafi'i

Praktis sejauh ini, kita merasakan adanya problematika dalam kajian keislaman. Sementara berbagai persoalan hukum senantiasa berdatangan, yang hingga kini pun belum ditemukan solusinya. Inilah di antara beberapa agenda permasalahan yang mendesak, yang memerlukan lahirnya metodologi sistematis yang relevan dalam melakukan upaya-upaya reformulasi hukum Islam kontemporer. Sebab lain yang ikut mendorong upaya reformulasi hukum sebagaimana gambaran di atas, adalah karena masih banyaknya sikap mendua di kalangan umat Islam yang segera diluruskan.

Pertama, banyak yang berpendirian bahwa bunga dalam bank itu haram. Perdirian ini tentu didasarkan dari teks al-Qur'an. Sementara dalam kenyataannya mereka tidak hanya hidup

${ }^{8}$ N urcholis Madjid, Kaki Langit Peradaban Islam (J akarta: Paramadina, 1997), 77. 
dengan bunga deposito, melainkan dalam kesehariannya mereka banyak yang menggunakan jasa bank. Lebih dari itu mereka mendirikan bank dengan sistem bunga, dengan alasan dł̆rurah. Padahal seperti yang telah dipahami bersama dalam sural al-Baqarah ayat 173, mengatakan bahwa darurat itu dengan syarat tidak ada unsur kesengajaan dan tidak lebih dari pemenuhan kebutuhan esensial.

Kedua, dalam pembagian harta warisan, al-Qur'an surat al-Nisa' ayat 11, dengan jelas mengatakan bahwa hak anak laki-laki adalah dua kali lebih besar dari hak perempuan. Namun dalam realitasnya ketentuan teks tersebut lebih banyak ditinggalkan oleh masyarakat Islam Indonesia, baik secara langsung atau tak langsung. ${ }^{9}$

Demikian pula persoalan hukum yang berkenaan dengan zakat. Ada sebanyak 32 ayat yang tersebar di dalam 19 surat dalam al-Qur'an, di mana ayat tersebut isinya hanya sekedar penjelasan yang menyangkut perintah untuk mengeluarkan zakat, tanpa menjelaskan apa, bagaimana dan berapa kewajiban zakat itu. Penjelasan Nabi yang berbentuk $\mathrm{h}$ \$dith mengelompokkan barang zakat itu kepada binatang ternak yang berkaki empat, bahan makanan yang bersifat vital, emas, perak dan tijarah. Formulasi dari kalangan mujtahid ketika itu menjelaskan binatang dan makanan yang hanya ada di negeri Arab dan lingkungannya.

J ika umat Islam konsekuen terhadap formulasi kitab-kitab fiqh tersebut, maka negeri-negeri lain yang hasil serta iklimnya berbeda dengan negeri Arab pada waktu itu, tidak akan memperoleh kesempatan untuk melakukan rukun Islam. Sebut saja misalnya, Indonesia, binatang unta bagi bangsa Indonesia adalah binatang yang langka, yang hanya ada di kebun binatang tertentu, itu saja hampir punah. Sementara kurma dan gandum adalah jenis tumbuh-tumbuhan yang tidak bisa hidup di Indonesia. Dalam formulasi fiqh tradisional, orang yang sudah mempunyai kambing sejumlah 40 ekor sudah dikenakan zakat. Sementara hasil cengkeh, teh, pala dan kopra yang bernilai jutaaan rupiah, secara teks ketika itu belum pernah disebut dalam kitab-kitab fiqh. Ini sama halnya orang yang miskin dikenakan zakat, sedang yang kaya bebas dari kewajiban tersebut. ${ }^{10}$ Termasuk hasil yang diperoleh dari penginapan, baik umum maupun jenis penginapan untuk mahasiswa (kos-kosan). Secara teks hasil dari penginapan itu belum teradopsi dalam teks aturan zakat secara legal-formal.

Dalam al-Qur'an terdapat paling sedikit empat ayat yang berisi pemberian izin penggunaan budak-budak sahaya sebagai pengatur alternatif bagi kebutuhan biologis kaum pria di samping istrinya. Ayat dimaksud antara lain surat al-Nisa sayat 3, al-Mukminun ayat 6, al-Ahzab ayat 52 dan al-Ma'asij ayat 30. Pada permulaannya Nabi memang pernah menghimbau untuk memposisikan mereka sebagaimana layaknya manusia biasa, lebih dari itu ada anjuran untuk membebaskannya. H anya saja semangat anjuran tersebut hingga ia wafat, perbudakan tetap saja belum bisa dihapuskan.

Persoalan kemudian yang muncul adalah apa kata dunia terhadap Islam jika hingga saat ini hanya berdasar ayat tersebut, sebagai nas \$3 sharih dan dalil qat/3ismasih mampu mempertahankan status quo sikap Islam terhadap perbudakan yang pernah terjadi pada saat

\footnotetext{
${ }_{9}^{9}$ M unawir Sadzali, G agasan Ajaran Islam : dalam Kontekstualisasi Ajaran Islam (J akarta: Paramadina, 1995), 87-88.

${ }^{10}$ Amir Syarifuddin, Pemabaharuan, 108.
} 
Nabi? Tentu konsep ini sangat bertentangan dengan $\mathrm{HAM},{ }^{11}$ di mana konsep yang terakhir tersebut juga telah diilhami oleh semangat ajaran Islam.

\section{Kesimpulan}

Hukum Islam turun dalam rangka memberikan aturan normatif dan sosiologis kepada manusia untuk mencapai kehidupannya yang layak. Tekanan maupun ikatan yang melekat dalam hukum apapun -yang kadang dirasakan oleh komunitas tertentu - pada hakikatnya tidak akan pernah terjadi jika cara pandang mereka terhadap hukum itu secara holistik, tidak sempit dan sepihak. Karena di balik sisi-sisi ikatan atau "nadhiras terdapat sisi-sisi penggembira "bashira". Dalam terminologi al-asma'>al-hysnasmisalnya, hukum tuhan itu senantiasa menggunakan pendekatan keseimbangan. J ika hukum itu mengandung muatan mengancam, pasti di balik itu ada muatan melindungi. J ika dalam hukum itu memuat hegemoni (al-J ahr) maka di situ pula mengandung muatan-muatan responsif (al-latif), demikian seterusnya.

Cara pemahaman inilah yang akan mengantarkan sikap pemahaman manusia yang konprehensif dalam melihat karakteristik hukum. Dengan begitu manusia tidak akan memiliki cara pandang yang mendua. Di satu sisi berpegang dengan kokohnya terhadap pemahaman teks al-Q ur'an yang tidak menyapa lingkungan budayanya, di pihak lain,-karena perkembangan budaya, pengaruh tempat dan waktusemangat hukum selalu menghendaki irama perubahan. Dengan demikian apa yang terlihat sekarang adalah munculnya sikap ambivalensi terhadap hukum, yaitu seakan-akan amat banyak kehendak Tuhan yang secara teks tidak terlaksana di dalam amalan. Padahal, hal yang demikian bukan berarti tidak terlaksananya hukum Tuhan secara teks. Anggapan demikian karena mereka memandang bahwa teks hukum Tuhan itu sebagai benda mati yang tidak memiliki fungsi-fungsi dialektik dengan konteksnya. Oleh karena itu, konstruksi fiqih tradisional yang telah berdialek pada zamannya, menuntutadanya rekonstruksi baru terhadap konteks kekinian. Sebab jika langkah ini tidak dilakukan, maka sikap mendua sebagaimana yang diungkap di atas akan terjadi. Sikap ini sepertinya wajar, mengingat formulasi figh lama, sudah banyak yang harus mengalami reaktualisasi. Lantaran fiqh sepertinya kurang tersedia jawaban-jawaban yang mampu menampung munculnya masalah-masalah baru. Sejumlah persoalan inilah yang menjadi embrio munculnya kebutuhan reformulasi hukum Islam kini dan yang akan datang. Tidak menutup kemungkinan beberapa rumusan figh yang hendak kita tawarkan sekarang, pada perkembangan berikutnya juga akan mengalami penyikapan yang sama. Beginilah idealnya fiqh, selalu bergesekan, berdialektik secara intensif dan tarik-menarik dengan kebutuhan masyarakat dan zamannya.

${ }^{11}$ Munawir Sadzali, “Gagasan Ajaran Islam”, dalam Kontekstualisasi Ajaran Islam (J akarta: Paramadina, 995), 9394. 


\section{Daftar Rujukan}

Amir Syarifuddin. Pembaharuan Pemikiran dalam Hukum Islam. Padang: Angkasa Raya. 1993. Cik H asan Bisri (ed). H ukum Islam dalam Tatanan Masyarakat Indonesia. J akarta: Logos. 1998.

Munawir Sadzali. Gagasan Ajaran Islam : dalam Kontekstualisasi Ajaran Islam. Jakarta: Paramadina, 995.

M. Hudlari Bek. Tarikh Tashri'>al-Islami. Mesir: al-Maktabah al-Tashri'yah al-Kubra, tt.

Manshur Amin dan Ismail S. Ahmad (ed). Dialog Pemikiran Islam dan Realitas Empirik. Yogyakarta: LKPSM NU.1993.

Nurcholis Madjid. Kaki Langit Peradaban Islam. J akarta: Paramadina, 1997.

Roscoe Pound. An Introduction to the Philosopy of Law ; Pengantar Filsafat Hukum. diterjemah oleh M. Radjab. J akarta: B hratara,1989.

Roibin. Respon Agama di Tengah Perubahan Sosial., makalah diseminarkan pada mahasiswa angkatan 2001/2002 STAIN Malang. 12/8/2001.

Syafi'i Ma'arif. Islam dan Masalah-masalah Kenegaraan. J akarta: LP3S. 1985. 